\title{
UPAYA GURU PPKN DALAM MENGIMPLEMENTASIKAN NILAI-NILAI DEMOKRASI PANCASILA PADA PESERTA DIDIK KELAS VII-11 DI SMP NEGERI 2 KOTA TERNATE
}

\author{
Oktosiyanti MT Abdullah ${ }^{1}$, Natalia Umawaitina ${ }^{2}$ \\ ${ }^{1}$ Dosen Program studi Pendidikan Pancasila dan Kewarganegaraan FKIP Unkhair \\ ${ }^{2}$ Mahasiswa Program studi Pendidikan Pancasila dan Kewarganegaraan FKIP Unkhair
}

Email: oktosiyantimtabdullah@gmail.com

$\begin{array}{ll}\text { Diterima } & : 21-02-2019 \\ \text { Direvisi } & : 28-03-2019 \\ \text { Dipublikasi } & : 01-05-2019\end{array}$

Abstrak. Penelitian ini bertujuan untuk mengkaji lebih dalam tentang faktor-faktor apa yang menghambat guru PPKn dalam mengimplementasikan nilai-nilai demokrasi Pancasila. Metode yang digunakan dalam penelitian ini adalah metode kualitatif deskriptif. Penelitian kualitatif adalah prosedur penelitian yang meneliti terkait dengan upaya guru PPKn dalam mengimplementasikan nilai-nilai demokrasi Pancasila pada peserta didik kelas VII-11 SMP Negeri 2 Kota Ternate. Subyek penelitian adalah guru dan peserta didik. Sumber data yang diguankan dalam penelitian ini adalah data primer dan data sekunder. Teknik pengumpulan data adalah teknik observasi, wawancara dan studi dokumentasi. Hasil penelitia menujukan bahwa upaya guru PPKn dalam mengimplementasikan nilai-nilai demokrasi Pancasila pada peserta didik kelas VII-11 SMP Negeri 2 Kota Ternate telah terlaksana dengan baik. Hal ini dibuktikan dengan sikap respon peserta didik terhadap praktek nilai-nilai demokrasi Pancasila. Faktor-faktor penghambat guru PPKn dalam mengimplementasikan nilai-nilai demokrasi Pancasila pada peserta didik kelas VII-11 SMP Negeri 2 Kota Ternate bisa diatasi dan pengimplementasian terlaksana dengan baik.

Kata Kunci: Upaya Guru PPKn, Implementasi Nilai, Demokrasi Pancasila, SMP Negeri 2 Kota Ternate.

\section{PENDAHULUAN}

Salah satu bidang yang sangat pokok dalam menentukan kemajuan bangsa adalah bidang pendidikan. Pendidikan nasional menurut Undang-Undang Nomor 20 Tahun 2003 bahwa Pendidikan Nasional berfungsi mengembangkan kemampuan dan membentuk watak serta peradaban bangsa yang bermartabat dalam rangka mencerdaskan kehidupan bangsa, bertujuan untuk berkembangnya potensi peserta didik agar menjadi manusia yang beriman dan bertaqwa kepada Tuhan Yang Maha Esa, berakhlak mulia, sehat dan berilmu, cakap, kreatif. mandiri, dan menjadi warga negara yang demokratis serta bertanggung jawab. Untuk dapat mendukung tercapainya tujuan pendidikan tersebut maka diperlukan peran serta dari berbagai pihak yaitu yang merupakan tanggung jawab masyarakat, keluarga dan pemerintah untuk menindak lanjuti hal tersebut di atas (Yusuf \& Hasyim, 2016).

Oleh karena itu, pendidikan merupakan suatu unsur yang tidak dapat dipisahkan dari diri manusia, mulai dari kandungan sampai beranjak dewasa kemudian tua manusia mengalami proses pendidikan yang didapatkan dari orang tua,masyarakat, maupun lingkungannya. Pendidikan merupakan kebutuhan bagi manusia, sebab tanpa pendidikan manusia akan sulit berkembang dan bahkan akan terbelakang (Afifuddin, 2008).

Pendidikan Pancasila dan Kewarganegaraan merupakan wahana untuk mengembangkan dan melestarikan nilai luhur dan moral yang berakar pada budaya dan bangsa Indonesia yang diharapkan dapat diwujudkan dalam bentuk perilaku dalam kehidupan sehari-hari, baik sebagai individu maupun sebagai anggota masyarakat, warga Negara. Perilaku yang dimaksudkan tersebut seperti yang tercantum di dalam penjelasan Undang-Undang tentang Sistem Pendidikan Nasional, Pasal 39 ayat 2, yaitu 
perilaku yang memancarkan iman dan takwa terhadap Tuhan Yang Maha Esa dalam masyarakat yang terdiri dari berbagai golongan agama, perilaku yang bersifat kemanusiaan yang adil dan beradab, perilaku yang bersifat persatuan bangsa dalam masyarakat yang beraneka ragam kepentingan.Perilaku yang mendukung kerakyatan yang mengutamakan kepentingan bersama di atas kepentingan perorangan dan golongan sehingga perbedaan pemikiran, pendapat, atau kepentingan tersebut melalui musyawarah mufakat serta mendukung upaya untuk mewujudkan keadilan sosial seluruh rakyat Indonesia.Dalam kehidupan bangsa Indonesia diakui bahwa nilai pancasilah adalah pandangan (filsafat hidup) yang berkembang dalam sosial budaya Indonesia. Nilai pancasila dianggap sebagai nilai dasar dan puncak (sari-sari) budaya bangsa (Abdi Guru, 2006: 130).

Manusia sangat membutuhkan pendidikan melalui proses penyadaran yang berusaha menggali dan mengembangkan potensi dirinya melalui metode pengajaran atau dengan cara lain yang telah diakui oleh masyarakat. Pendidikan tidak mengenal usia, dalam arti bahwa sampai usia tuapun manusia berhak mendapatkan pendidikan. Peranan pendidikan sangat besar dalam mewujudkan manusia yang utuh dan mandiri serta menjadi manusia yang mulia dan bermanfaat bagi lingkungannya, dengan pendidikan manusia akan paham bahwa dirinya itu sebagai makhluk yang dikaruniai kelebihan dibandingkan dengan makhluk lainnya. Bagi negara, pendidikan memberikan kontribusi yang sangat besar terhadap kemajuan suatu bangsa dan merupakan wahana dalam menerjemahkan pesan-pesan konstitusi serta membangun watak bangsa. Niilai dalam sila-sila pancasila yang secara filosofis, merupakan filosofis bangsa Indonesia sebelum mendirikan bangsa. Atas dasar pengertian filosofis tersebut maka dalam hidup bernegara nilai-nilai Pancasila merupakan dasar filsafat Negara. Konsekuensinya dalam setiap aspek penyelenggaraan Negara harus bersumber pada nilai-nilai Pancasila termasuk sistem peraturan perundang-undangan di Indonesia. Oleh karena itu realisasi kenegaraan termasuk dalam proses reformasi dewasa ini merupakan suatu keharusan bahwa Pancasila merupakan sumber nilai dalam pelaksanaan kenegaraan baik dalam pembangunan nasional, ekonomi, politik, hukum, social budaya, maupun pertahanan dan keamanan. Pancasila dianggap sebagai sesuatu yang sakral yang setiap warganya harus hafal dan mematuhi segala isi dalam Pancasila tersebut. Namun sebagian besar warga Negara Indonesia hanya menganggap Pancasila sebagai dasar Negara/ideologi semata tanpa memperdulikan makna dan manfaatnya dalam kehidupan (John Shadily 2001:111).

Pendidikan bertujuan untuk mengembangkan kemampuan dan membentuk watak serta peradaban bangsa yang bermartabat dalam rangka mencerdaskan kehidupan bangsa. Di samping itu pendidikan bertujuan untuk mengembangkan potensi peserta didik agar menjadi insan yang beriman dan bertakwa kepada Tuhan Yang Maha Esa, berkhlak mulia, sehat, berilmu, cakap, kreatif, mandiri, menjadi warga negara yang demokratis, bertanggung jawab, serta dapat berdedikasi. Ada dua hal utama yang melatar belakangi perlunya suatu pedoman untuk menghayati dan mengamalkan Pancasila sebagai pandangan hidup bangsa dan negara yaitu pengamalan serta menyongsong masa depan. Sebagai generasi saat ini, jika kita tidak ikut merasakan betapa susahnya kemerdekaan ini, akan tetapi diharuskan untuk berjuang meneruskan perjuangan para pemimpin. Dengan cara meneruskan perjuangan, melakukan hal yang positif dan bermanfaat bagi kita sendiri dan orang lain. Namun sangat ironi pada saat ini Pendidikan pengamalan dan penghayatan pancasila tidak lagi menjadi pedoman hidup masyarakat Indonesia (Cristine dan Kansil. 2011).

Kondisi keberadaan tenaga guru sebagaimana diuraikan di atas, dan dengan mempertimbangkan potensi sumberdaya manusia tersedia memperlihatkan perlu upaya nyata, berkesinambungan dan terpadu dari pemerintah daerah Kota Ternate, khususnya Dinas Pendidikan Nasional Kota Ternate. Dengan melalui Biro Kepegawaian Daerah (BKD) sebagai operasional kebijakan di bidang kepegawaian untuk melakukan rekruitmen dan pemerataan kebutuhan tenaga guru serta meningkatkan profesionalitasnya. Dengan harapan akan mampu menghasilkan sumberdaya manusia yang memiliki kualitas kinerja yang tinggi dan para guru yang mampu mengembangkan kapasitas secara lebih profesional. Apabila kebutuhan tenaga guru tersebut dapat dilaksanakan dengan tepat akan diperoleh manfaat yang besar bagi pemerintah Kota Ternate untuk meningkatkan sumberdaya manusia melalui peningkatan pendidikan didaerahnya (Hasyim \& Yusuf, 2017). Berdasarkan latar belakang tersebut, tulisan ini ingin 
menjawab bagaimana upaya guru PPKn dalam mengimplementasikan nilai-nilai demokrasi Pancasila pada peserta didik kelas VII-11 di SMP Negeri 2 Kota Ternate.

\section{METODE PENELITIAN}

Tipe yang digunakan dalam penelitian ini adalah tipe penelitian kualitatif deskriptif. Penelitian kualitatif deskriptif adalah suatu metode dalam meneliti status kelompok manusia, suatu objek, suatu sistem pemikiran, atau pemikiran yang terjadi pada sekarang yang bertujuan untuk memberikan deskripsi, gambaran atau lukisan secara sistematis dan akurat mengenai faktor-faktor, sifat-sifat serta hubungan antara fenomena yang di selediki (Moh. Nasir, 1999).

Penelitian ini dilaksanakan di SMP Negeri 2 Kota Ternate. Lokasi penelitian tersebut dipilih karena pertimbangan pertama adalah unsur keterjangkauan lokasi penelitian oleh peneliti. Pelaksanaan studi di lokasi yang dipilih tidak menimbulkan masalah dalam kaitannya dengan kemampuan tenaga peneliti. Adapun alasan lain yang tidak kalah pentingnya dan pertimbangan yang lebih mendasar dalam pemilihan lokasi penelitian ini adalah adanya karakteristik khusus pada peserta didik di sekolah yang akan diteliti.

Subyek ialah unsur yang mewakili seseorang yang melakukan perbuatan atau aktivitas tertentu. Subjek dalam penelitian ini adalah kepala sekolah, guru PPKN dan peserta didik. Dalam penelitian kualitatif penentuan subjek penelitian dilakukan saat peneliti mulai membuat rancangan penelitian. Dalam proses di lapangan, untuk menentukan siapa yang akan dikenai perlakuan khusus akan digunakan teknik wawancara sesuai dengan kondisi subjek di lapangan.

\section{Teknik Pengumpulan dan Analisis Data}

Pengumpulan data dilakukan dengan teknik observasi, wawancara, dan studi dokumentasi.

a. Teknik Observasi

Dalam proses pengumpulan data, penulis menggunakan teknik observsi yaitu pengamatan dan pencatatan secara sistematis tentang respon peserta didik (Hadi,19987 : 37). Dalam hal ini observasi yang dilakukan dalam penelitian ini meneliti tentang upaya guru PPKn dalam mengimplementasikan nilai-nilai demokrasi Pancasila pada peserta didik kelas VII -11SMP Negeri 2 Kota Ternate.

b. Teknik Wawancara

Dalam penelitian ini, penulis memilih bentuk wawancara semi terstruktur yang dimana dilakukan secara terang-terangan (overted interview) dan menempatkan responden sebagai sejawat (viewing one another as peers). Alasan penulis menggunakan teknik wawancara semi terstruktur adalah untuk memberikan kesempatan kepada seorang atau responden untuk menyatakan dan menangkap pernyataan secara mendetail.

c. Teknik dokumentasi

Teknik ini dikenal dengan penelitian dokumentasi (documentatio research) yang mencari data melalui beberapa arsip dan dokumen sejarah sekolah, raport, surat kabar, majalah, jurnal, buku dan benda-benda tulis lainnya yang relevan (Arikunto,1993:201). Dalam penelitian ini, metode dokumentasi digunakan juga untuk mengumpulkan data tentang upaya guru PPKN dalam mengimplementasikan nilai-nilai demokrasi Pancasila.

Ada empat tahap penting yang sangat berkaitan yang dimana terkait dengan analisa data, yaitu pengumpulan data, reduksi data, penyajian data dan penarik kesimpulan/verifikasi. Teknik analisis data model interaktif dalam penelitian ini di jelaskan sebagaiman langkah-langkah berikut: 
Oktosiyanti M.T. Abdullah dan Natalia Umawaitina. 2019. Upaya Guru PPKn, Implementasi Nilai, Demokrasi

Pancasila, SMP Negeri 2 Kota Ternate

a. Pengumpulan data

Kegiatan pengumpulan data dilakukan sejak peneliti memasuki lokasi penelitian sampai semua data yang diperlukan terkumpul. Pengumpulan data diperoleh dari hasil observasi, wawancara dan dokumen.

b. Reduksi data

Kegiatan yang dilakukan pada tahap ini adalah mengidenfikasi data dan mengkode data. Dalam pengkodean data digunakan tiga kolom terdiri dari nomor aspek pengkodean dan kode.

c. Penyajian data

Pada tahap ini adalah mengorganisasikan data yang suda direduksi. Data tersebut mula-mula disajikan secara terpisa antara satu tahap dengan tahap yang lain, tetapi setelah kategori terakhir direduksi maka keseluruhan data dirangkum dan disajikan secara terpadu.

d. Kesimpulan dan verifikasi

Dapat diketahui dari data yang diperoleh baik melalui observasi, wawancara maupun dokumentasi. Kesimpulan akhir diharapkan dapat diperoleh setelah pengumpulan data selesai.

\section{HASIL PENELITIAN DAN PEMBAHASAN}

\section{Upaya Guru PPKn Dalam Mengimplementasikan Nilai-Nilai Demokrasi Pancasila Pada Peserta Didik Kelas VII-11 Di SMP Negeri 2 Kota Ternate}

Berdasarkan hasil penelitian tentang upaya guru PPKn dalam mengimplementasikan nilai-nilai demokrasi Pancasila pada peserta didik kelas VII-11 di SMP Negeri 2 Kota Ternate menurut guru PPKn (inisial FY) menjelaskan bahwa dalam mengimplementasikan nilai-nilai demokrasi pancasila pada peserta didik kelas VII-11 sudah lebih dari cukup. Hal ini dapat dibuktikan bahwa di SMP Negeri 2 Kota Ternate peserta didik telah menerapkan prinsip dengan baik. Dalam mengimplementasikan nilainilai demokrasi Pancasila, selaku guru PPKn menjadi contoh atau panutan untuk peserta didik dan guruguru lainnya. Dengan demikian pendidikan merupakan usaha untuk membantu perkembangan potensi dan kemampuan anak agar bermanfaat bagi kepentingan hidupnya sebagai seorang individu dan sebagai anggota masyarakat atau warga Negara. Pendidikan dapat terlaksana dengan baik apabila terdapat keterkaitan yang didaktis dan pendagogis dari seluruh komponen pendidikan baik sarana maupun prasarana (Hayun \& Hasyim, 2018).

Dalam pemberian contoh terkait dengan nilai-nilai demokrasi Pancasila agar lebih bisa berjalan denan efektif dalam pengimplementasiannya yaiti dilakukan dengan cara memberikan materi serta contoh langsung yang harus dipraktekan oleh peserta didik itu sendiri. Hal ini tersebut sejalan denganpendapat Sjarkawi (2006: 29) mengatakan bahwa nilai adalah kualitas suatu hal yang menjadikan hal itu dapat disukai, diinginkan, berguna, dihargai, dan dapat menjadi objek kepentingan. Berdasarkan hasil penelitian menunjukkan bahwa peserta didik kelas VII-11 SMP Negeri 2 Kota Ternate menampilkan nilai-nilai demokrasi pancasila yang telah diterapkan di sekolah tersebut. Hal ini dapat terlihat dari setiap pengakuan peserta didik yang dalam berlaku adil dalam pemilihan ketua kelas, ketua osis dan wakil mereka selalu berlaku adil dan teratur dalam pemilihan mungkin seperti itu salah satu pengimplentasian nilai-nilai demokrasi yang dimana salah satu dari semua pengimplementasian cukup berhasil dimana mengingat juga masih sangat banyak peserta didik yang kurang suka belajar terkait dengan nilai-nilai demokrasi dengan alasan tidak suka dengan mata pelajaran PPKn.

Selanjutnya menurut guru PPKn (inisial HS) mengatakan bahwa dalam mengimplementasikan nilainilai demokrasi Pancasila saya selalu mengajarkan kepada peserta didik agar bisa menerapkan nilai-nilai dalam kehidupan sehari-hari. Dan dalam menerapkan nilai-nilai demokrasi Pancasila saya sebagai guru PPKn juga menjadi panutan bagi peserta didik, yang dimana saya juga selaku wali kelas peserta didik 
kelas VII-11. Dalam mengajarkan materi nilai-nilai demokrasi Pancasila biasanya saya membuat atau memecahkan masalah dengan memberikan contoh pemilihan ketua kelas dan menuntun peserta didik agar memilih secara langsung. Hal ini dapat dibuktikan dengan efektifnya pemberian contoh serta praktek langsung bagaimana peserta didik mengimplementasikan nilai-nilai demokrasi Pancasila. Hal ini sejalan dengan pendapat Nurul Zuriah (2007: 19) yang mengemukakan bahwa nilai adalah pola keyakinan suatu masyarakat tentang hal baik yaang harus dilakukan dan hal buruk yang harus dihindari dalam berprilaku. Seorang guru harus mengajarkan tentang nilai-nilai demokrasi Pancasila agar peserta didik lebih paham tentang nilai-nilai yang baik.

Selanjutnya menurut peserta didik kelas VII-11 (inisial SFZA) mengatakan bahwa upaya guru PPKn dalam mengimplementasikan nilai-nilai demokrasi Pancasila sudah baik karena saya dapat memahami apa itu nilai-nilai demokrasi Pancasila. Berdasrkan hasil penelitian maka peneliti berpendapat bahwa banyak peserta didik tersebut sudah bisa mengimplementasikan nilai-nilai demokrasi Pancasila dengan cukup baik, dimana peserta didik tersebut sudah sering mempraktekan maksud dari nilai-nilai tersebut. Contohnya ikut serta dalam pemilihan ketua osis dan peserta didik itu sendiri yang mengarahkan temantemannya untuk bisa ikut dalam pemilihan ketua OSIS tersebut (Hasil wawancara 18.11:2018)

Hal ini sejalan dengan pendapat Paul Suparno, dkk (2006: 75) yang menyatakan bahwa nilai-nilai demokrasi adalah hakikat sesuatu yang menyebabkan hal itu pantas dikejar oleh manusia. Maka penulis mengklarifikasi menurut peserta didik kelas VII-11(inisial SFZA) men gatakan bahwa upaya guru PPKn dalam implementasikan nilai-nilai demokrasi pancasila sudah baik karena siswa tersebut sudah dapat memahami apa itu nilai-nilai demokrasi Pancasila.

Selanjutnya menurut peserta ddik kelas VII-11 (inisial M. RA) mengatakan bahwa upaya guru PPKn dalam mengimplementasikan nilai-nilai demokrasi Pancasila membuat saya bisa memahami tentang nilai-nilai demokrasi Pancasila, dan yang saya pahami tentang nilai-nilai demokrasi Pancasila adalah tentang pemilihan ketua OSIS dan wakil ketua OSIS (Hasil wawancara 19.11:2018).

Hasil penelitian menunujukkan bahwa peserta didik tersebut dapat memahami nilai-nilai demokrasi Pancasila dengan baik yang dimana adanya implementasi daari guru PPKn cukup membuat peserta didik emrasa memiliki jati diri dan bisa menjadi warga negara yang lebih baik, serta yang paling penting dalam penerapan implementasi terssebut adalah kedisiplinan peserta didik dan tanggung jawab dari peserta didik itu sendiri bisa jadi lebih efektif. Hal tersebut sejalan dengan pendapat pendapat (Widiastono, 2004:25-26). Pendidikan kewarganegaraan adalah mata pelajaran yang digunakan sebagai wahana untuk mengembangkan dan melestarikan nilai luhur moral yang berakar pada budaya Bangsa Indonesia, yang diharapkan dapat mewujudkan dalam bentuk perilaku sehari-hari peserta didik, baik sebagai individu maupun sebagai anggota masyarakat dan makhluk ciptaan Tuhan yang Maha Esa (Depdikbud, 1997: 6). Maka penulis mengklarifikasikan bahwa Menurut peserta didik kelas VII (inisial M. RA), mengatakan bahwa belajar tentang nilai-nilai demokrasi sangatlah penting untuk itu perlu untuk belajar dan mengikuti materi yang di berikan oleh guru PPKn. Hal ini dapat di buktikan bahwa peserta didik kelas VII-11 memahami tentang nilai-nilai demokrasi Pancasila karena dalam melakukan atau memilih dalam pemilihan ketua kelas selalu bersikap adil dan tertib.

Selanjutnya menurut peserta didik (inisial SSJ), mengatakan bahwa dalam upaya guru PPKn dalam mengimplementasikan nilai-nilai demokrasi pancasila guru PPKn selalu membuat kami memahami nilai-nilai yang terkandung dalam demokrasi Pancasila.

Hasil penelitian menunjukkan bahwa adanya nilai-nilai yang diimplementasikan dalam sekolah dalam hal ini pada peserta didik byang dimana peserta didik tersebut sudah bisa mempraktekan nilai-nilai tersebut. Implementasi dari nilai-nilai tersebut cukup membuat peserta didik menjadi lebih memahami apa itu arti demokrasi dan bagaimana cara untuk mempraktekan nilai demokrasi itu sendiri. Hal tersebut sejalan dengan pendapat guru sebagai pembimbing dalam rangka kegiatan belajar mengajar harus mampu membantu siswa dalam rangka mencapai tujuan seperti yang di kemukakan oleh Roestiyah, 
Oktosiyanti M.T. Abdullah dan Natalia Umawaitina. 2019. Upaya Guru PPKn, Implementasi Nilai, Demokrasi

Pancasila, SMP Negeri 2 Kota Ternate

N.K., bahwa: "Seorang guru harus mampu menimbulkan semangat belajar individual. Masing-masing anak mempunyai perbedaan dalam pengalaman, dan sifat-sifat pribadi yang lain sehingga dapat member kebebasan pada anak untuk mengembangkan kemampuan berfikirnya dan penuh inisiatif dan kreatif dalam pekerjaan.

Maka penulis dapat mengklarifikasikan menurut pendapat peserta didik kelas VII (inisial SSJ). Mengatakan bahwa belajar tentang nilai-nilai demokrasi itu sangat penting karena didalam nilai-nilai tersebut memiliki makna dan arti yang baik, dan saya cukup paham apa yang di sampaikan oleh guru PPKn. Belajar tentang mata pelajaran PPKn itu penting dan saya paham apa yang di ajarkan, saya juga senang dalam belajar tentang nilai-nilai demokrasi pancasila karena saya juga senang dengan guru mata pelajarannya (Hasil wawancara 20.11.2018)

Selanjutnya menurut peserta didik kelas VII-11(inisial TH), mengatakan bahwa upaya guru PPKn dalam implementasikan nilai-nilai demokrasi pancasila sudah baik karena kami saya dapat memahami nilainilai demokrasi pancasila, nilai-nilai demokrasi pancasila itu contoh tentang pemilihan ketua osis dan wakilnya. Sesuai dengan apa yang diungkapkan oleh peserta didik tersebut amak penulis berpendapat bahwa sanya nilai-nilai demokrasi Pancasila sudah diimplementasikan dengan baik kepada peserta didik sehingga mereka sudah cukup memahami apa itu nilai-nilai yang terkandung dalam demokrasi Pancasila itu sendiri. Hal tersebut sesuai dengan pendapat Omar Muhammad Al-Taumy Al-Syalbany bahwa metode mengajar adalah jalan seorang guru untuk member paham kepada muridmuridnya dan merubah tingkah lakunya sesuai dengan tujuan-tujuan yang diinginkan". Maka penulis mengklarifikasikan bahwa menurut pendapat peserta didik kelas VII (TH), mengatakan bahwa upaya guru PPKn dalam mengimplementasikan nilai-nilai demokrasi Pancasila sudah baik (Hasil wawancara 21.11:2018).

Selanjutnya menurut peserta didik kelas VII-11 (inisial IM), mengatakan bahwa upaya guru PPKn dalam mengimplementasikan nilai-nilai demokrasi Pancasila sudah baik karena kami dapat memahami apa yang disampaikan tentang nilai-nilai demokrasi Pancasila yang di sampaikan oleh guru PPKn dalam materi tersebut, saya cukup memahami karena guru PPKn menerangkan dengan cukup baik.

Hal tersebut menunjukan bahwa implementasi dari nilai-nilai demokrasi Pancasila sudah terlaksana dengan baik, dari hasil penelitian maka peneliti berpendapat bahwa peserta didik terebut sudah cukup paham dengan apa yang diimplememtasika oleh guru PPKn pada mereka. Hal ini sejalan dengan pendapat E. Mulyasa mengungkapkan bahwa, "guru sebagai motivator hendaknya bertanggung jawab mengarahkan pada yang baik, harus menjadi contoh, sabar, dan penuh pengertian. Guru harus mampu menumbuhkan disiplin dalam diri (self dicipline). Maka penulis mengklarifikasikan menurut pendapat peserta didik kelas VII (inisial IM) mengatakan bahwa upaya guru PPKn dalam implementasikan nilainilai demokrasi pancasila sudah baik karena kami dapat memahami apa yang di sampaikan tentang nilai-nilai demokrasi pancasila. Yang di sampaikan oleh guru PPKn dalam materi tentang nilai-nilai demokrasi pancasila saya cukup memahami karena guru PPKn menerangkan dengan cukup baik.

Selanjutnya menurut peserta didik kelas VII-11 (inisial PM), mengatakan bahwa upaya guru PPKn dalam mengimplementasikan nilai-nilai demokrasi Pancasila sudah baik karena guru PPKn dalam menjelaskan tentang nilai-nilai demokrasi pancasila memberikan contoh yang membuat saya paham. Hal ini sejalan dengan pendapat Paul Suparno (2004:37). Nilai demokrasi merupakan nilai yang membentuk sikap tidak diskriminatif. Demokrasi pancasila menjunjung tinggi kesamaan hak setiap orang, yang artinya hak dirinya dan orang lain sama belajar. Maka penulis mengklarifikasikan bahwa menurut peserta didik kelas VII (inisial PM), mengatakan bahwa belajar tentang nilai-nilai demokrasi pancasila penting karena dengan belajar nilai-nilai demokrasi pancasila membuat kita paham arti nilainilai.

Selanjutnya menurut peserta didik kelas VII-11 (inisial SA), mengatakan bahwa upaya guru PPKn dalam mengajarkan peserta didik tentang nilai-nilai demokrasi Pancasila sudah baik karena sebagian besar dari kami sudah memahami nilai-nilai demokrasi Pancasila. Belajar tentang nilai-nilai demokrasi 
pancasila penting karena mengandung nilai-nilai yang baik untuk dipelajari. Kadang saya kurang paham apa yang di ajarkan tapi guru PPKn dalam mengajarkan selalu mengulang-ngulang materi tentang nilainilai demokrasi Pancasila sehingga saya sudah cukup mengerti, meskipun saya masih sering sedikit bingung (Hasil wawancara, 22.11:2018)

Dari hasil penelitian maka peneliti berpendapat bahwa peserta didik tersebut sedikit paham dari apa yang telah ia pelajari selama ini, dimana adanya pengimplementasian dari nilai-nilai demokrasi Pancasila dia sudah sedikit memahami meskipun masih bingung dengan cara mempraktekannya. Hal tersebut sejalan dengna pendapat Abd. Rahman Assegaf (2004: 140-141) yakni pendidikan yang menerapkan sistem andragogi menuntut keaktifan peserta didik untuk berbuat. Sekolah berperan untuk mengembangkan potensi, bakat, dan minat peserta didik serta memfasilitasi keanekaragaman karakter peserta didik. Maka penulis mengklarifikasikan bahwa menurut peserta didik kelas VII (inisial SA) mengatakan bahwa upaya guru PPKn dalam mengajarkan peserta didik tentang nilai-nilai demokrasi pancasila sudah baik karena sebagian besar dari kami sudah memahami nilai-nilai demokrasi pancasila. Belajar tentang nilai-nilai demokrasi pancasila penting karena mengandung nilai-nilai yang baik untuk dipelajari (hasil wawancara 23.11:2018).

Penulis mengidentifikasi hasil wawancara, dokumentasi dan teori-teori yang relevan maka dapat dianalisis bahwa upaya guru PPKn dalam mengimplementasikan nilai-nilai demokrasi Pancasila pada peserta didik kelas VII SMP Negeri 2 Kota Ternate sudah cukup efektif meskipun masih ada juga sebagian peserta didik yang masih belum bisa mengimplementasikan nilai-nilai tersebut. Praktek dari peserta didik untuk bagaimana mengimplementasikan nila-nilai demokrasi Pancasila yang dimaksud dalam penelitian ini salah satunya adalah praktek demokrasi yang berjalan dengan sangat baik, dan hal itu sudah ditunjukkan oleh peserta didik kelas VII SMP Negeri 2 kota Ternate.

Menyadari betapa pentingnya peningkatan kualitas pendidikan, pemerintah Kota Ternate telah melakukan berbagai upaya, termasuk diantaranya mengeluarkan Surat Keputusan Walikota dalam rangka menata sistem perencanaan tentang rincian tugas pada Dinas Pendidikan Nasional Kota Ternate meliputi: susunan organisasi, kepala dinas, bagian tata usaha, bagian umum, bagian kepegawaian, bagian perencanaan dan evaluasi, sub dinas pendidikan dasar dan taman kanak-kanak, sub dinas menengah, umum, dan kejuruan, cabang-cabang dinas dan unit pelaksanaan teknis Diknas. Sehingga diharapkan program-program pendidikan yang dihasilkan oleh sistem perencanaan tersebut berhasil membawa masyarakat meraih tujuan pendidikan yang dicita-citakan (Rajaloa \& Hasim, 2018).

\section{Faktor-faktor Yang Menghambat Guru PPKn Dalam mengimplementasikan Nilai-Nilai Demokrasi Pancasila}

Berdasarkan hasil wawancara dengan guru PPKn (inisial FY) mengatakan bahwa faktor-faktor yang menghambat guru PPKn dalam mengimplementasikan nilai-nilai demokrasi Pancasila adalah kurangnya minat peserta didik yang mau belajar patuh terhadap nilai-nilai yang sudah diajarkan. Hal ini dapat dilihat dari aktifitas peserta didik yang dimana meskipun praktek dari nilai-nilai demokrasi Pancasila sudah lumayan dilakukan akan tetapi masih kurang efektif (Hasil wawancara, 24.11:2018)

Berdasarkan hasil wawancara tersebut, penulis berpendapat bahwa faktor utama yang menghambat guru PPKn dalam mengimplementasikan nilai-nilai demokrasi Pancasila adalah peserta didik yang masih sangat minim pengetahuannya terkait dengan nilai-nilai tersebut, akhirnya minat untuk mempraktekan nilai-nilai tersebut masih kurang terlaksana dengan baik. Hal ini sejalan dengan pendapat Darmawan, (2007), mengemukakan bahwa ada beberapa faktor yang mempengaruhi tetapi tergantung didikan dan ajaran yang selalu diajarkan, jika ajakan dan bimbingan selalu menuju ke arah yang baik maka dengan sendirinya karakter peserta didik akan terbentuk ke arah yang baik.

Selanjutnya menurut guru PPKn (inisial HS), mengatakan bahwa faktor-faktor yang menghambat guru PPKn dalam mengimplementasikan nilai-nilai demokrasi Pancasila adalah minimnya solidaritas pada lembaga sekolah kami, yang dimana masih banyak guru-guru lain misalnya yang tidak mau ikut serta 
dalam mengimplementasikan nilai-nilai demokrasi Pancasila. Hal tersebut dapat dilihat dari aktifitas guru-guru yang kurang mau memberikan arahan kepada peserta didik terkait dengan pentingnya nilainilai demokrasi Pancasila. Kondisi seperti ini sejalan dengan teori yang diungkapkan oleh Ivonna Indah dkk (2003: 69), penanaman nilai demokrasi pancasila hendaknya dilakukan kepada peserta didik sedini mungkin untuk membentuk kepribadian anak. Penanaman nilai demokrasi Pancasila ditransformasikan oleh guru melalui kegiatan belajar mengajar. Ada beberapa faktor yang mempengaruhi tersebut namun tidak menjadi persoalan dalam mengimplementasikan nilai-nilai demokrasi Pancasila.

Selanjutnya menurut peserta didik kelas VII-11(inisial SFZA), mengatakan bahwa faktor-faktor yang menghambat guru PPKn dalam mengimplementasikan nilai-nilai demokrasi Pancasila yaitu kemampuan guru PPKn yang masih tidak terlalu menguasai materi, saya contohkan ada beberapa guru PPKn yang masih honor dan dia mungkin masih perlu banyak belajar lagi. Hal ini dapat dilihat dari cara penyampaian atau praktek dari implementasi dari nilai-nilai demokrasi Pancasila. Hal ini sejalan dengan pendapat Arief. S. Sadiman (2001: 2-4) menyebutkan bahwa sekolah yang menerapkan nilai-nilai demokrasi pancasila guru yang bersikap demokratis. Guru dapat menerima perbedaan, menghargai pendapat siswa, tidak menjadi satu-satunya sumber belajar, dan menciptakan suasana belajar yang demokratis. Jika implementasi demokrasi nilai-nilai pancasila terdapat beberapa kendala maka sedemikian cara seorang guru untuk punya beberapa cara yang bisa dalam menerapkan nilai-nilai tersebut termasuk beberapa faktor tersebut.

Selanjutnya menurut peserta didik kelas VII-11 (inisial M. RA) mengatakan bahwa faktor-faktor yang menghambat guru PPKn dalam mengimplementasikan nilai-nilai demokrasi Pancasila adalah temanteman yang sering tidak mau ikut belajar untuk membantu supaya guru kami bisa mengimplementasikan nilai-nilai dengan baik. Ada juga teman-teman saya yang sering kali bolos dan tidak mau ikut dalam pelajaran PPKn.

Peran guru tidaklah terbatas di dalam masyarakat, bahkan pada hakikatnya merupakan komponen yang strategis yang memilih peran penting dalam menentukan gerak maju kehidupan bangsa. Bahkan keberadaan guru merupakan faktor condisio since quanon yang tidak mungkin digantikan oleh komponen mana pun dalam kehidupan bangsa sejak dulu, terlebih-lebih pada era kontemporer ini. Keberadaan guru sebagai suatu bangsa amatlah penting, apalagi bagi suatu bangsa yang sedang membangun, terlebih-lebih bagi keberlangsungan hidup bangsa di tengah-tengah lintasan perjalanan zaman dengan teknologi yang kian cangih dan segala perubahan serta pergeseran nilai yang cenderung memberi nuansa kepada kehidupan yang menuntut ilmu dan seni dalam kadar dinamika untuk dapat mengadaptasikan. Semakin akurat para guru melaksanakan fungsinya, semakin terjamin tercipta dan terbinanya kesiapan dan keandalan seseorang sebagai manusia pembangunan. Dengan kata lain, potret dan wajah diri bangsa dimasa depan tercermin dari potret diri para guru masa kini, dan gerak maju dinamika kehidupan bangsa berbanding lurus dengan citra para guru di tengah-tengah masyarakat (Hasyim \& Yusuf, 2017).

Berdasarkan hasil penelitian terkait dengna faktor yang menghambat guru dalam mengimplementasikan nilai-nilai demokrasi Pancasila adalah minimnya pengetahuan peserta didik terkait dengna nilai-nilai demokrasi, dan kurangnya minat belajar peserta didik sehingga guru juga mengalami kesulitan dalam mengimplementasikan nilai-nilai tersebut. Hal tersebut sejalan dengna pendapat Ahmad D. Marimba (Hasbullah, 2006:17) mengatakan bahwa guru atau pendidik adalah orang yang memikul pertanggungjawaban untuk mendidik. Tugas seorang guru adalah mengajarkan kepada peserta didiknya tentang apapun yang berhubungan dengan pelajaran, kalaupun terdapat kendala-kendala itu sudah menjadi hal yang wajar tinggal bagaimana mengatur strategi agar semua berjalan normal sesuai rencana.

Selanjutnya menurut peserta didik kelas VII-11(inisial SSJ) mengatakan bahwa faktor-faktor yang menghambat guru PPKn dalam mengimplementasikan nilai-nilai demokrasi Pancasila adalah kurangnya pengetahuan seorang guru dalam mengimplementasikan nilai-nilai demokrasi Pancasila, dan faktor lain juga yaitu teman-teman yang nakal dan susah diatur. Berdasarkan hal tersebut maka peneliti 
berpendapat bahwa faktor utama yang menghambat guru dalam mengimplementasikan nilai-nilai demokrasi Pancasila adalah guru yang masih minim pengetahuannya sehingga peserta didik juga kurang paham dengan baik terkait dengan nilai-nilai demokrasi Pancasila yang diimplementasikan oleh guru tersebut. Hal ini sejalan dengna pendapat Sutari Imam Barnadib (Arif Rohman, 2009: 149) mengatakan bahwa pendidik adalah setiap orang yang dengan sengaja mempengaruhi orang lain untuk mencapai tingkat kemanusiaan yang lebih tinggi. Dengan kemampuan seorang guru pasti dapat mempengaruhi peserta didik agar bisa memahami materi dari implementasi nilai-nilai demokrasi Pancasila. Seorang guru punya pengaruh agar bisa membuat peserta didik menjadi lebih paham terkait dengan materimateri yang diberikan walaupun banyak faktor-faktor yang mempengaruhi.

Selanjutnya menurut peserta didik kelas VII-11(inisial TH) mengatakan bahwa ada beberapa faktor yang berpengaruh dalam implementasi nilai-nilai demokrasi Pancasila, yaitu faktor kemampuan seorang guru dalam menjelaskan nilai-nilai demokrasi Pancasila, karena jika guru PPKn tidak memiliki kemampuan maka kami juga gagal dalam memahami apa yang disampaikan.

Dari hasil penelitian, maka peneliti berpendapat bahwa faktor pengetahuan seorang guru PPKn dalam mengimplementasikan nilai-nilai demokrasi Pancasila sangat perlu agar peserta didik mempunyai minat yang tinggi untuk mau mengimplementasikan nilai- nilai tersebut. Hal ini sejalan dengan pendapat Sutari Imam Barnadib, Lan ge velt (Arif Rohman, 2009: 149) mengatakan bahwa pendidik adalah orang yang dengan sengaja membantu orang lain untuk mencapai kedewasaan. Kemampuan guru dalam meningkatkan disiplin belajar berkaitan dengan kemampuan guru dalam menanggulangi disiplin peserta didik. Bila ada beberapa faktor yang berpengaruh maka akan menghambat proses implementasi nilainilai demokrasi pancasila, tetapi jika seorang guru memiliki kemampuang yang cukup maka akan terasa biasa dan gampang.

Selanjutnya menurut peserta didik kelas VII-11 (inisial IM) mengatakan bahwa dalam mengimplementasikan nilai-nilai demokrasi Pancasila ada beberapa faktor yang menghambat yaitu ada faktor kemampuan, jika seorang guru PPKn tidak memiliki kemampuan dalam menjelaskan nilai-nilai demokrasi Pancasila maka akan kami sebagai peserta didik juga tidak akan paham. Hal ini dapat dilihat dari minimnya pengetahuan guru terhadap nilai-nilai demokrasi Pancasila sehingga peserta didik juga dalam mempraktekan nilai-nilai-nilai tersebut kurang berjalan dengan efektif. Hal ini sejalan dengan pendapat Suryobroto (1997) faktor yang mempengaruhi kemampuan guru antara lain:

a) Kepribadian yang menyangkut tingkah laku, wibawa, karakter dan lain-lain yang akan berpengaruh terhadap proses interaksi.

b) Penguasaan bahan pengajaran.

c) Penguasaan kelas.

d) Cara guru berbicara atau berkomunikasi dengan peserta didik.

e) Cara menciptakan suasana kelas yang kondusif.

f) Memperhatikan prinsip individualitas.

g) Standar kelulusan.

Dari beberapa faktor tersebut bisa saja mempengaruhi peserta didik dalam mengimplementasikan nilainilai demokrasi Pancasila karena jika seorang guru tidak memiliki kemampuan dan pengetahuan yang baik akan berdampak pada peserta didik.

Selanjutnya wawancara dengan peserta didik kelas VII-11 (inisial PM) mengatakan bahwa bahwa faktor-faktor yang menghambat guru PPKn dalam mengimplementasikan nilai-nilai demokrasi Pancasila adalah faktor ikut-ikutan teman sebaya, makanya saya malas untuk belajar mata pelajaran ini. Selain mata pelajaran ini membosankan dan juga gurunya saya kurang suka (Hasil wawancara 25.11:2018)

Berdasarkan hasil penelitian, maka peneliti berpendapat bahwa yang menjadi penghambat tercapainya pengimplementasian nilai-nilai demokrasi Pancasila adalah faktor malas peserta didik untuk 
mengimplementasikan nilai-nilai tersebut. Sehingga guru yang disalahkan dalam hal ini guru PPKn yang katanya membosankan menurut salah satu peserta didik di atas. Hal ini sejalan dengan pendapat Rusman (2009) mengatakan bahwa tahap merancang kegiatan pembelajaran adalah tahap yang akan berhubungan dengan kemampuan guru menguasai bahan ajar. Guru PPKn haruslah memiliki kesiapan dalam mengajarkan materi yang disampaikan pada peserta didik apalagi dalam mengimplementasikan nilai-nilai Pancasila pada siswa untuk diterapkan dalam kehidupan sehari-hari, peserta didik haruslah paham tentang nilai-nilai yang diajarkan oleh guru PPKn.

Selanjutnya menurut peserta didik kelas VII-11 (inisial SA) mengatakan bahwa bahwa faktor-faktor yang menghambat guru PPKn dalam mengimplementasikan nilai-nilai demokrasi Pancasila adalah kurang suka dengan mata pelajaran PPKn, karena selain gurunya suka marah-marah ditambah saya sangat kurang suka dengan cara guru PPKn mengajar. Dari hasil penelitian, maka peneliti berpendapat bahwa peserta didik tersebut tidak serius untuk mau belajar, terlebih lagi peserta didik tersebut kuarng suka dengan mata pelajaran PPKn yang katanya itu yang menjadi alasan peserta didik untuk tidak mau mengimplementasikan nilai-nilai demokrasi Pancasila (Hasil wawancara.26.11:2018)

Hal ini sejalan dengan pendapat Suprayati dalam Kunandar, keterampilan mengajar adalah sejumlah kompetensi guru yang menampilkan kinerjanya secara profesional. mengimplementasikan nilai-nilai demokrasi Pancasila merupakan tugas seorang guru yang bertanggung jawab sebagai seorang pengajar, kalaupun ada beberapa kendala yang menghambat dalam mengimplementasikan nilai-nilai demokrasi Pancasila maka guru yang harus pintar-pintar seorang mengatasi kendala tersebut.

Penulis mengidentifikasi hasil wawancara, dokumentasi, dan teori-teori yang relevan maka dapat dianalisis bahwa faktor utama yang menghambat guru dalam mengimplementasikan nilai-nilai demokrasi Pancasila adalah minimnya pengetahuan peserta didik terkait dengan nilai-nilai demokrasi itu sendiri, dan juga masih kurangnya pengetahuan guru terkait dengna nilai-nilai demokrasi Pancasila, serta faktor malas peserta didik untuk mempraktekkan nilai-nilai tersebut. Saat ini, kesadaran dan rasa nasionalisme pada kalangan generasi muda sudah semakin menipis. Padahal perjuangan para pendahulu kita amat sangat berat dengan mengorbankan jiwa dan raga hanya untuk mencapai satu cita-cita yaitu Kemerdekaan bagi seluruh rakyat Indonesia. Seharusnya kita yang saat ini menikmati karunia ini bisa menghargai hasil jerih payah para pejuang kita khususnya untuk generasi muda yang mulai minimnya pemahaman generasi muda akan nilai budayanya, dimana generasi cenderung lebih senang men gikuti budaya barat yang jauh dari norma dan adat istiadat bangsa (Mohtar Kamisi dan Rustam Hasyim, 2016).

Akan tetapi peserta didik yang minim pengetahuannya dengan peserta didik yang lumayan bisa dan mau mempraktekan nilai-nilai tersebut masih lumayan banyak sehingga terhambatnya pengimplementasian tersebut masih bisa diatasi. Sekolah adalah lembaga pendidikan yang berfungsi sebagai pendukung utama sistem pendidikan di Indonesia. Dengan dukungan sekolah dan peran serta Guru dan Siswa sistem pembelajaran dapat berjalan dengan baik. Terlebih lagi jika didukung sarana dan prasarana yang lengkap, tentu dapat memotivasi siswa untuk belajar dengan serius dan bisa meraih prestasi. Tidak dipungkiri bahwa pendidikan di masa ini sudah banyak dipengaruhi budaya global. Pesatnya pengaruh budaya global yang tersebar luas dan mudah sangat cepat dapat mempengaruhi cara pandang, gaya hidup dan budaya suatu bangsa. Arus budaya global dengan cepat membanjiri kita, seolah-olah tidak memberi kesempatan kepada kita untuk menyerap dengan filter mental dan sikap kritis. Di sisi lain budaya global juga dapat membawa dampak positif dan dampak negatif,artinya mencirikan bahwa budaya global adalah hal yang krusial bisa membangun atau menurunkan moral budaya bangsa kita (Yusuf \& Hasyim, 2016).

\section{KESIMPULAN}

Dari hasil penelitian dan pembahasan tersebut dapat disimpulkan sebagai berikut :

1) Upaya guru PPKn dalam mengimplementasikan nilai-nilai demokrasi Pancasila pada peserta didik kelas VII-11 di SMP Negeri 2 Kota Ternate berjalan dengan cukup baik. Hal ini dibuktikan dengan yang di sampaikan oleh guru PPKn yang mengimplementasikan nilai-nilai demokrasi Pancasila 
dimana sebagian besar peserta didik disekolah tersebut sudah mengerti dan paham akan nilai-nilai demokrasi Pancasila.

2) Ada beberapa faktor yang menghambat guru PPKn dalam mengimplementasikan nilai-nilai demokrasi pancasila tetapi sebagai guru PPKn tidak memiliki rasa patah semangat dalam berusaha mengimplementasikan. Hal ini dapat dilihat dari mulai guru PPKn mengajarkan dan selalu mengingatkan peserta didik nilai-nilai yang terkandung dalam demokrasi pancasila.

3) Upaya guru PPKn dalam mengimplementasikan nilai-nilai demokrasi Pancasila di SMP Negeri 2 Kota Ternate haruslah dijaga dan dikembangkan agar peserta didiklebih giat dan lebih baik lagi dalam mengingatkan peserta didik terkait dengan nilai-nilai demokrasi Pancasila.

4) Agar tidak merasa gagal dalam mengajarkan kepada peserta didik kelas VII-11 dalam mengimplementasikan nilai-nilai demokrasi Pancasila. Guru berharap dapat melakukan yang terbaik pada peserta didik, semoga peserta didik dapat mengerti dan paham dari apa yang diajarkan oleh seorang guru PPKn.

\section{DAFTAR PUSTAKA}

Budiningsih, Asri. (2004). Pembelajaran moral berpijak pada karakteristik siswa dan budayanya. Jakarta :Rineka Cipta

Cahyono. (200) Budi Pekerti dalam Perspektif Pendidikan. Malang. Dirjen Pendidikan Dasar dan Menengah Pusat penetaran Guru IPS.

Dobbert and Winkler. 1986. Social Problems. Sydney: Allyn.

Depdiknas 2003. UU No 23 Tahun 2003 tentang Sistem Pendididkan Nasional, Jakarta

Departemen Pendidikan Dan Kebudayaan, 2005, UU. RI. No. 20 Tahun 2003 Tentang Sistem Pendidikan Nasional, Sinar Grafika: Jakarta

Dwi Siswoyo, dkk. 2005. Psikologi Anak-anak. Jakarta: Rajawali.

Darmadi Hamid. (2009) Dasar Konep Pendidikan Moral Bandung: Alfabet

Mohtar Kamisi dan Rustam Hasyim," Peranan Guru Dalam Membangun Kesadaran Cinta Tanah Air pada Siswa Sekolah dasar (Telaah Teoritik)" dalam Jurnal PEDAGOGIK, FKIP Unkhair 2016.

Margono, S. 1997. Metode Penelitian Pendidikan, Rineka Cipta, Jakarta.

Nani I. Rajaloa dan Rustam Hasim, "Manajemen Perencanaan Dan Rekrutmen Tenaga Pendidik Oleh Dinas Pendidikan Kota Ternate", Dalam Jurnal Edukasi FKIP Unkair. Vol. 16 No.1 Januari 2018.

Nasir M. 1999. Metode Penelitian, Ghalia Indonesia, Jakarta

Nurul Z, 2007. Metodologi Penelitian Ilmu Sosial dan Pendidikan Teori dan Aplikasi, Bumi Aksara, Jakarta.

Nasution S., 2007. Metode Research, Bumi aksara, Jakarta

Rustam Hasyim, "Peranan Orang Tua Dalam Pembentukan Moral Siswa di SD Negeri Tabam Kecamatan Kota Ternate Utara, dalam Jurnal PEDAGOGIK, FKIP Unkhair 2016.

, dan MukhtarYusup "Supervisi Pembelajaran Kepala Sekolah Dalam Meningkatkan Kompentensi Guru IPS dI SMP Negeri 2 Kota Ternate”, Dalam Jurnal EDUKASI Vol. 15 No.1 Januari 2017.

Subhan Hayun "Peranan Kepala Sekolah Sebagai Supervisior Dalam Meningkatkan Kualitas Pembelajaran (Telaah Teortik), DALAM Jurnal EDUKASI, Vol. 16No.2Juni 2018. dan Nani I Rajaloa, Mukhtar Yusuf "Manajemen Sumberdaya Manusia Tenaga Pendidik Oleh Dinas Pendidikan Kota Ternate “ dalam Jurnal Penelitian Humano, Vol. 8 No. 2 Edisi November 2017.

Soenarjati. 1989. Metode Penelitian. Jakarta: Ghalia Indonesia.

Sudarwan D, 2002. Menjadi Peneliti Kualitatif, Pustaka Setia, Bandung

Supriya Dan Winataputra. 2004. Pendididkan Kewarganagaraan: Model Pengembangan Materi dan Pembelajaran. FPIPS UPI: Bandung

Sardiman. 2005. Interaksi dan Motivasi Belajar Mengajar. Jakarta: Raja Grafindo Persada.

Zuchdi. 2003. Psikologi Remaja. Jakarta: BPK Gunung Mulya. 